\title{
Routine fetal RHD genotyping with maternal plasma: a four-year experience in Belgium
}

\author{
Jean-Marc Minon, Christiane Gerard, Jean-Marc Senterre, Jean-Pierre Schaaps, and Jean-Michel Foidart
}

From the Department of Laboratory Medicine, the University Department of Fetal Medicine, and the University Department of Obstetrics and Gynecology, Centre Hospitalier Régional de la Citadelle, Liège; and the Department of Transfusion Medicine, University Hospital, Liège, Belgium.

\begin{abstract}
:
Background: The objective was to evaluate the diagnostic value of $R H D$ fetal genotyping from the plasma of D- mothers as soon as 10 weeks' gestation in a routine clinical practice in Belgium.

Study design and methods: A prospective study was conducted between November 2002 and December 2006. DNA extraction was performed in an automated closed tube system. Fetal RHD/SRY genotypes were detected in the plasma of 563 pregnant mothers by real-time polymerase chain reaction (PCR) targeting multiple exons 4,5 , and 10 of the $R H D$ gene and targeting an $S R Y$ gene sequence. These were compared to the D phenotypes determined in the 581 babies they delivered.

Results: By combining amplification of three exons, the concordance rate of fetal RHD genotypes in maternal plasma and newborn D phenotypes at delivery was 100 percent ( $99.8 \%$ including one unusual false-positive). The presence of nonfunctional $R H D$ genes and the absence of a universal fetal marker, irrespective of fetal sex, did not influence the accuracy of fetal $\mathrm{RhD}$ status prediction. The $R H D$ genotyping from 18 twin pregnancies was also assessed. Five weak D women were excluded from the $R H D$ fetal genotyping prediction. Three discrepant results $(0.5 \%)$ between predicted fetal genotype and cord blood phenotype were not confirmed by the baby phenotypes from venipuncture blood.

Conclusion: Prenatal prediction of fetal RHD by targeting multiple exons from the maternal plasma with realtime PCR is highly sensitive and accurate. Over 4 years, this experience has highly modified our management of D- pregnant women.
\end{abstract}

Abbreviations: $\mathrm{Ct}=$ cycle threshold; $\mathrm{HDFN}=$ hemolytic disease in fetuses and newborns.

Despite the use of anti-D immunoglobulin (RhIG) prophylaxis, RhD (D) alloimmunization still remains the major cause of severe hemolytic disease in fetuses and newborns (HDFN). ${ }^{1} \mathrm{ABO} / \mathrm{D}, \mathrm{Rh} / \mathrm{Kell}$ typing of red cells, and alloantibody detection in the blood of pregnant women is routinely performed to identify pregnancies at risk for HDFN, to identify D- women who need RhIG prophylaxis, and to provide compatible blood for obstetric emergencies. ${ }^{2}$ When anti-D is detected, the knowledge of fetal D status aids in the management of HDFN. When using this approach, it was custom to phenotype the putative father (Fig. 1). Based on the probability that the fetus had inherited the RHD gene (RHD), serial assessment of maternal antibody titers was performed with indirect antiglobulin test (IAT) in saline at $37^{\circ} \mathrm{C}$. $^{3}$ If the titer was high or was rising to a significant level, then invasive amniocentesis was made. Measurements of the optical density ( $\triangle \mathrm{OD} 450 \mathrm{~nm}$ ) and fetal RHD genotyping were determined from the amniotic fluid.

In 1998, Lo and coworkers ${ }^{4}$ demonstrated cell-free fetal DNA in plasma and serum from pregnant women. This has led to the development of noninvasive real-time polymerase chain reaction (PCR) assays to detect fetal $R H D$ during pregnancy ${ }^{5,6}$ Antenatal management of anti-D-alloimmunized women has been modified as a result of this new molecular approach in combination with Doppler ultrasonography of the fetal middle cerebral artery. ${ }^{7,8}$ The peak systolic waves of middle cerebral artery will gradually supplant amniocentesis to detect severe fetal anemia. The time has come to "put the needles away" when assessing D fetal status, evaluating affected fetuses and managing pregnancy ${ }^{9}$ Our clinical diagnostic laboratory implemented this noninvasive fetal $R H D$ genotyping in 2002 .

Several studies have described fetal $R H D$ genotyping techniques with maternal plasma. ${ }^{10}$ A few European teams in the United Kingdom, ${ }^{11}$ France, ${ }^{12,13}$ and the Netherlands ${ }^{14}$ have reported their experiences with these techniques in clinical routine practice. ${ }^{15}$ This report discusses our experiences in evaluating $R H D$ fetal genotype from the maternal plasma of D- mothers in a clinical routine practice in Belgium. 
Fig. 1. Algorithm for clinical management of RhD-anti-D-alloimmunized patients in the first affected pregnancy.

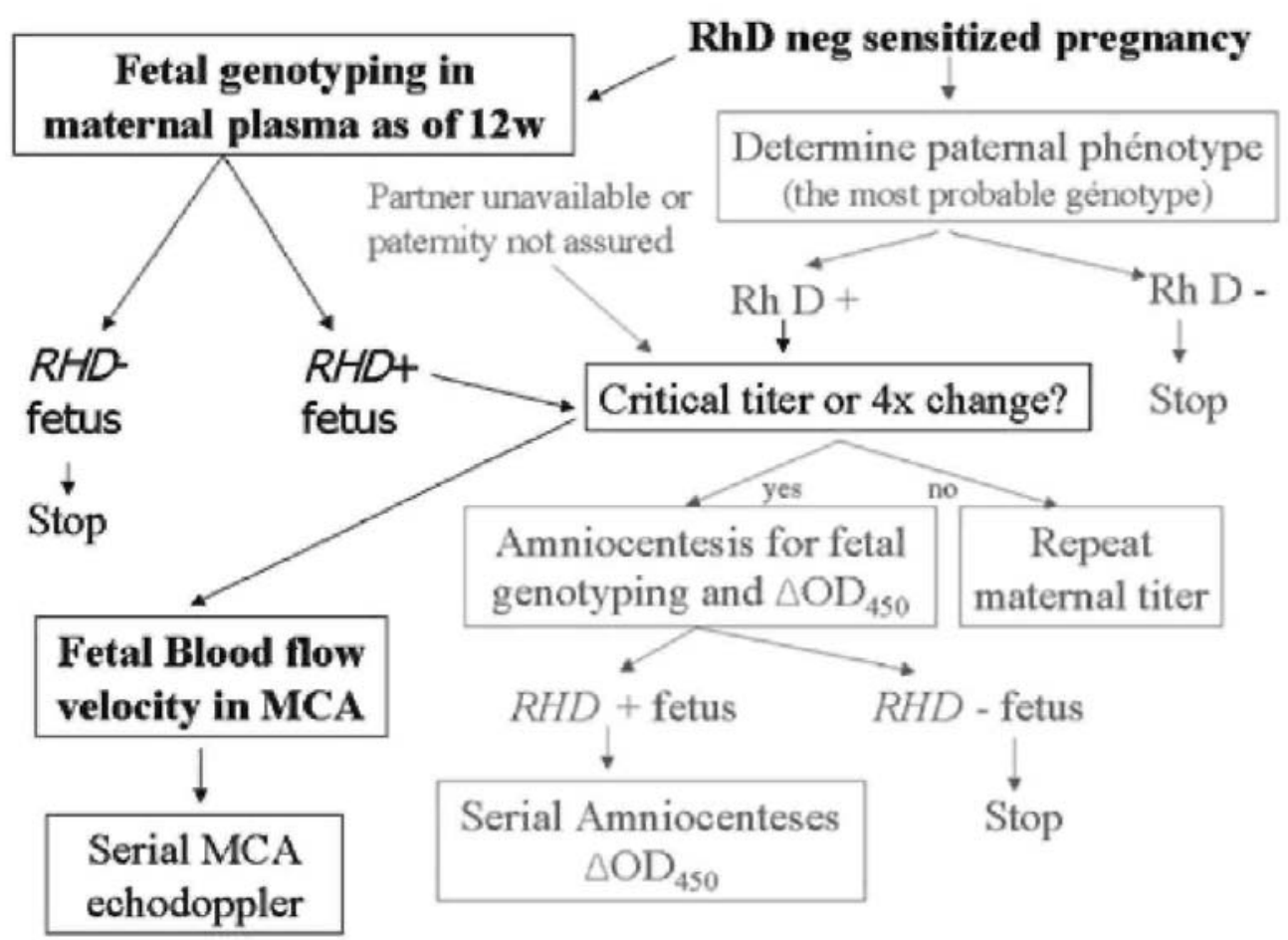

\section{MATERIALS AND METHODS}

\section{Subjects}

After informed consent, blood samples from 563 D- pregnant women came from our own gynecology obstetric department as well as other Belgian hospitals via post or couriers. The major indications were the management of anti-D-alloimmunized patients or patients at risk of $\mathrm{D}$ alloimmunization before the use of invasive procedures or potentially sensitizing obstetrical events. Since 2006, this noninvasive method for determining fetal RHD genotypes has been proposed for all D- pregnant women at our hospital.

Eighteen patients had a twin pregnancy. The 563 results of the fetal RHD genotype were compared to the $581 \mathrm{D}$ phenotypes of the newborns. The mean gestational age at which genotyping was carried out was 19.7 weeks (median, 17.5 weeks; range, 10-38 weeks). Forty women were tested during the first trimester $(<14 \mathrm{SA} ; 7.1 \%)$, 409 were tested during the second trimester $(<27 \mathrm{SA} ; 72.7 \%)$, and 114 were tested during the third trimester $(20.2 \%)$. Twenty-two pregnant women were of black African origin.

\section{Samples}

Maternal (and paternal) peripheral blood was collected in evacuated tubes containing ethylenediaminetetraacetate and stored at room temperature. Most samples were received within 24 hours of blood collection, and after 48 hours, the samples were no longer used. Within 48 hours, the blood samples were centrifuged at $1700 \times \mathrm{g}$ for 10 minutes. The maternal plasma was transferred to three polypropylene sterile microtubes and frozen at less than $-20^{\circ} \mathrm{C}$ until further processing. The maternal (and paternal) buffy coat was separately frozen under the same conditions. Cord blood samples were provided at birth to confirm the D status of fetuses by Rh serotyping. In mothers undergoing amniocentesis, $R H D$ genotyping was also confirmed from the amniotic fluid.

\section{DNA extraction}

Automatic DNA extraction was performed with an automated sample preparation system (Cobas Ampliprep, Roche Diagnostics, Vilvoorde, Belgium) with the total nucleic acid isolation kit (Roche Diagnostics). DNA was 
extracted from $850 \mu \mathrm{L}$ of maternal plasma, the maximal volume to be processed by the instrument. The final elution volume was $70 \mu \mathrm{L}$. A $10-\mu \mathrm{L}$ aliquot of the extracted DNA was used for amplification. Two extractions per women were made from two aliquoted micro-tubes. When relevant, $200 \mu \mathrm{L}$ of buffy coat and $500 \mu \mathrm{L}$ of amniotic fluid samples were extracted in the same manner. Eluate from the buffy coat was prediluted at 1 in 1000. Two internal controls were added to each extraction series: a positive control extracted from the buffy coat of a $\mathrm{D}+$ man, at a concentration of 20 to $80 \mathrm{ng}$ per $\mu \mathrm{L}$, diluted $(1 / 1000 \mathrm{vol} / \mathrm{vol})$ with plasma from a D-women, and a negative control consisting of plasma from a D- women.

\section{RHD genotyping}

Quantitative real-time PCR was performed with the TaqMan technology with a sequence detector (ABI Prism 7700, Applied Biosystems, Foster City, CA) and primers and probes synthesized by Eurogentec (Liège, Belgium). To enhance specificity, three regions in the RHD (exons 4, 5, and 10) were targeted. The characteristics and sequences of the primers and probes used in the RHD real-time PCR assays were similar to those previously reported. ${ }^{16}$ In brief, $R H D$ exons 4 and 5 were adapted from Finning and colleagues, ${ }^{17}$ generating a 71- and 82-bp amplicon, respectively. These real-time PCR assays detected RHD but not the nonfunctional $R H D \psi$ or RHD-CE-D hybrid genes. Real-time PCR of the 3'UTR from RHD exon 10 was identical to that shown by Lo and coworkers ${ }^{5}$ (74-bp amplicon). With this last assay, the exon 10 sequence of $R H D \psi$ or RHD-CE-D hybrid genes was also amplified. To evaluate the efficiency of the DNA extraction procedure and to confirm that male fetal DNA was present in the maternal plasma, CCR5 (the universal chemokine receptor gene) and the Ychromosome linked $S R Y$ gene sequence (83-bp amplicon) were amplified.

To improve sensitivity, two real-time PCR replicates per RHD exon were carried out. The final elution volume from one extraction $(70 \mu \mathrm{L})$ did not allow to analyze each PCR in duplicate $(10 \mu \mathrm{L}$ per PCR). Therefore, one real-time PCR per RHD exon was done, respectively, on each extract. A duplex real-time PCR amplified exon 10 and $C C R 5$ in the same well. Each extract was tested for $S R Y$ in a monoplex and an $S R Y /$ exon 5 duplex realtime PCR.

Amplification results were reported by cycle threshold $(\mathrm{Ct})$, that is, the calculated cycle number at which the PCR products crossed a detection threshold. The higher the initial amount of target DNA, the lower the Ct value.

\section{Interpretation criteria}

A fetus was characterized as $R H D+$ if at least one of two replicates was positive for all three $R H D$ exons. When there were discrepancies between the three $R H D$ exons, real-time PCR assays targeting the exons with negative results were repeated on two additional replicates prepared from a new extract of the last preserved maternal plasma. The maternal (and paternal) buffy coats were tested with the same assay. If the discrepancy persisted without any amplification of maternal genomic DNA, the result was considered inconclusive and a new blood sample was obtained for reanalysis. Males were predicted if at least two of four SRY results were positive.

To prevent false-positive due to $R H D \psi$ or $R H D-C E-D$ hybrid genes, fetuses were considered negative when no amplifications were detected for both $R H D$ exon 4 and $R H D$ exon 5 whatever the PCRs of exon 10 . In the case of isolated amplification of exon 10, a conventional PCR-based test for detecting RHD, RHD $\psi$, the $\mathrm{C}$ and $\mathrm{c}$ alleles of RHCE (described by Singleton et al. ${ }^{18}$ ), was performed from the maternal (and paternal) genomic DNA of conserved white blood cells (WBCs) to confirm the presence of a nonfunctional gene. The partner was analyzed when the exon 10 real-time PCR on maternal buffy coat was negative.

When the Ct from three RHD exons was abnormally low ( $<5$ th percentile), real-time PCR was performed on maternal WBC DNA to assess the presence of maternal $R H D$. The real-time-PCR was considered negative when no signal was observed before the 45 th cycle of amplification.

\section{RESULTS}

\section{Correlation between the results of $R H D$ genotyping of DNA from the maternal plasma and the RhD phenotypes of newborns}

For the 545 singleton pregnancies, fetal $R H D$ and $S R Y$ genotyping from the maternal plasma predicted 90 RHD-/ $S R Y$ - fetuses, $95 R H D$-/SRY+ fetuses, $176 R H D+/ S R Y$-fetuses, and $184 R H D+/ S R Y+$ fetuses. A total of 544 
results were confirmed by the birth of 266 girls, of whom 90 were D- and 176 D+, and the birth of 278 boys, of whom 95 were D- and 183 D+. Overall, 66.1 percent of RHD+ fetuses and 33.9 percent negative were found, 51.2 percent of SRY+ fetuses and 48.8 percent negative were observed (Table 1$)$. Sensitivity of the D status prediction was thus 100 percent (no false-negatives). The specificity was 100 percent after the exclusion of one unusual false-positive from the plasma of a solid organ transplant recipient. This last one was observed in a 37-year-old D- pregnant patient who had received an amniocentesis to determine the fetal karyotype, as previously reported. ${ }^{19}$ The patient was 16.6 weeks pregnant, and real-time PCR in the maternal plasma showed amplification of exons $4,5,10$, and $S R Y$, indicating that the fetus was a $\mathrm{D}+$ male. $\mathrm{Ct}$ values of the amplifications were identical to those observed for the other D+ male fetuses (mean Ct of exons 4, 5, 10, and $S R Y$ were 40.4, 37.1, 38.7, and 38.8, respectively). The real-time PCR of all exons and $S R Y$ were negative in the amniotic cells. This discrepancy between invasive and noninvasive results invalidated fetal $R H D$ genotyping from the maternal plasma. The patient's history told us that the patient had received a kidney transplant from a $\mathrm{D}+$ male donor. In October 2005, a D- girl was born. It should be noted that the RHD and $S R Y$ were still found in the maternal plasma 3 days after birth.

Three other results revealed discrepancies between the fetal genotype and cord blood phenotype. These three discrepancies $(0.5 \%)$ are worth commenting on (Table 2$)$. In the first case, baby venipuncture, for diagnostic purpose, confirmed that the phenotype and genotype matched. In the second case, the mother refused a venipuncture for her baby but accepted a buccal swab. The RHD genotype deduced from the buccal cells was similar to that determined from maternal plasma. None of these mothers received the appropriate RhIG prophylaxis. In the third case, the obstetrician reported a discrepancy between the genotype and newborn phenotype. It was recommended that an $\mathrm{ABO} / \mathrm{D}$ control group and a search for a weak $\mathrm{D}$ be included. These analyses confirmed the RHD genotype result. Moreover, the direct antiglobulin test result was negative.

No discrepancies were found with regard to sex prediction in the whole series.

TABLE 1. Singleton pregnancies: correlation between RHD genotyping of DNA from maternal plasma and the RhD phenotypes of the newborns at birth

\begin{tabular}{lllll|}
\hline \multirow{2}{*}{$\begin{array}{c}\text { Gestation } \\
\text { (weeks) }\end{array}$} & Number & \multicolumn{2}{c}{ Fetal $R H D$ genotyping from maternal plasma } & \multicolumn{1}{c}{$\begin{array}{c}\text { Concordant } \\
\text { results* }(\%)\end{array}$} \\
\cline { 2 - 5 } $10-13$ & 39 & $26 / 13$ & $21 / 18$ & 100 \\
$14-26$ & 396 & $260 / 136$ & $195 / 201$ & $100 \dagger$ \\
$27-38$ & 110 & $74 / 36$ & $63 / 47$ & 100 \\
Total & 545 & $360 / 185(66.1 \% / 33.9 \%)$ & $279 / 266(51.2 \% / 48.8 \%)$ & $100 \dagger$ \\
\hline
\end{tabular}

* Concordant results confirmed by fetal D phenotyping on baby blood samples and infant sex.

$\uparrow 100$ percent concordance when the patient with a kidney transplant from a D + male kidney donor was excluded.

\section{Ct value of each real-time PCR assay: descriptive statistics}

The amplification efficiencies of the assays specific for $R H D$ exons 5, 10, and $S R Y$ were comparable, each having a similar median Ct value. A lower efficiency was observed for exon 4, however (Table 3 ). The Ct values of different real-time PCR assays, with the exception of the CCR5 assay, correlated poorly with gestation age. Correlation coefficients were between 0.2 and 0.4 . All slopes were negative and significantly different from zero (data not shown).

The sensitivity of each real-time PCR assay (the number of positive replicates out of the total performed from the D+ fetuses) was $86.8,97.1$, and 96.9 percent for exons 4, 5, and 10, respectively. Sensitivity for $S R Y$ (the number of positive replicates out of the total performed from the male fetuses) was 94.9 percent. Seventy-seven of 360 women bearing a D+ fetus exhibited at least one negative replicate and 19.5 percent (15/77) presented two negative replicates for a specific $R H D$ exon. Fourteen of them showed two negative replicates for exon 4 $(3.9 \%)$, none for exon 5, and one for exon $10(0.3 \%)$. In these 15 patients with failed amplification of exons 4 or 10, real-time PCR was repeated in duplicate from a third extraction of preserved maternal plasma and the absence of exon 4 amplification remained only for two. Real-time PCR on the maternal buffy coat DNA did not reveal amplification of the $R H D$ gene region. The fetal $\mathrm{RhD}$ status predictions were inconclusive for these two patients and required a new blood sample from patients to provide conclusive results. 
The absence of amplification was not related to gestational age. Indeed, of 77 patients, the mean gestational age was 19.7 weeks (median, 17.5 weeks), compared to 18.6 weeks (median, 17.1 weeks) in the 283 others. The difference was not significant $(\mathrm{p}=0.14 ; \mathrm{t}=1.489$ ). No extraction failures of fetal DNA was observed, that is, all negative PCR results from the first extract with all positive PCR results from the second one.

TABLE 2. Four discrepant results (0.7\%) observed between the fetal genotype and the cord blood phenotype

\begin{tabular}{|c|c|c|c|c|c|c|c|c|c|}
\hline \multirow[b]{2}{*}{ Patients } & \multirow[b]{2}{*}{$\mathrm{gw}$} & \multicolumn{2}{|c|}{$\begin{array}{c}\text { Plasma maternal } \\
\text { genotype }\end{array}$} & \multicolumn{2}{|c|}{$\begin{array}{l}\text { Newborn phenotype* } \\
\text { (cord blood) }\end{array}$} & \multicolumn{2}{|c|}{$\begin{array}{l}\text { Baby phenotype* } \\
\text { (venipuncture) }\end{array}$} & \multicolumn{2}{|c|}{$\begin{array}{l}\text { Other cell } \\
\text { genotypes }\end{array}$} \\
\hline & & $R H D$ & $S R Y$ & RhD & sexe & RhD & sexe & $R H D$ & $S R Y$ \\
\hline 1. SM & 16 & + & + & - & + & + & + & NA & $\mathrm{NA}$ \\
\hline 2. $\mathrm{BF}$ & 22 & + & - & - & - & NA & NA & $+\dagger$ & $-\dagger$ \\
\hline 3. NM & 25.3 & + & - & $-t$ & - & $+\S$ & - & NA & NA \\
\hline 4. FI & 16.6 & + & + & - & - & - & - & $-\mathrm{II}$ & $-\mathrm{II}$ \\
\hline $\begin{array}{l}\text { * Identical } \\
\dagger \text { Buccal ce } \\
+ \text { Weak D t } \\
\text { § Weak exp } \\
\text { II Amniocy }\end{array}$ & $\begin{array}{l}\text { serologic } n \\
\text { ls. } \\
\text { sting not } p \\
\text { ession of } D \\
\text { es. }\end{array}$ & $\begin{array}{l}\text { iods. } \\
\text { rmed. }\end{array}$ & & & & & & & \\
\hline
\end{tabular}

TABLE 3. Ct value of each real-time PCR assay: descriptive statistics

\begin{tabular}{llllllc}
\hline \multicolumn{1}{c}{ Target } & Mean & Minimum & 5th percentile & Median & 95th percentile & Maximum \\
\hline RHD exon 4 & 40.2 & 34.9 & 37.8 & 40.1 & 42.6 & 44.0 \\
RHD exon 5 & 36.4 & 31.5 & 34.0 & 36.4 & 38.7 & 43.7 \\
RHD exon 10 & 36.9 & 29.4 & 34.5 & 36.9 & 39.3 & 42.7 \\
SRY monoplex & 37.4 & 32.3 & 35.2 & 37.3 & 39.8 & 43.0 \\
SRY duplex* & 37.2 & 30.9 & 35.0 & 37.1 & 39.6 & 42.0 \\
CCR5† & 35.5 & 25.8 & 33.1 & 35.5 & 37.8 & 43.0 \\
\hline
\end{tabular}

* SRY duplex = assay for exon 5 and SRY.

$\dagger$ Duplex assay for exon 10 and CCR5.

TABLE 4. Examination of patients with isolated exon 10 amplification

\begin{tabular}{|c|c|c|c|c|c|c|c|c|}
\hline & & $\begin{array}{r}\text { Real-time } \\
\text { maternal } \\
\text { exons } 4,5\end{array}$ & $\begin{array}{l}\text { PCR on } \\
\text { plasma } \\
5, \text { and } 10\end{array}$ & $\begin{array}{l}\text { Real-tim } \\
\text { buffy cor } \\
\text { exons 4, }\end{array}$ & $\begin{array}{l}\text { e PCR on } \\
\text { t maternal } \\
5 \text {, and } 10 \\
\end{array}$ & & & \\
\hline Patients & $\begin{array}{c}\text { Racial } \\
\text { background }\end{array}$ & Exon $10(\mathrm{Ct})$ & Exons 4/5 & Exon 10 & Exon $4 / 5$ & $\begin{array}{c}\text { Maternal } \\
\text { Rh } \\
\text { phenotype } \\
\end{array}$ & $\begin{array}{c}\text { Convent. PCR on } \\
\text { maternal/paternal } \\
\text { buffy coat }\end{array}$ & $\begin{array}{c}\text { Newborn } \\
\text { Rh } \\
\text { phenotype }\end{array}$ \\
\hline 1 & $\mathrm{~A} / \mathrm{A}$ & $+(30.7)$ & - & + & - & cde/cde & Maternal $R H D \psi$ & cde/cde \\
\hline 2 & $\mathrm{~A} / \mathrm{A}$ & $+(32.7)$ & - & + & - & cde/cde & Maternal RHD $\psi$ & cde/cde \\
\hline 3 & $\mathrm{~A} / \mathrm{A}$ & $+(32.4)$ & - & + & - & cde/cde & Maternal $R H D \psi$ & cde/cde \\
\hline 4 & $\mathrm{~A} / \mathrm{U}$ & $+(33.7)$ & - & + & - & $\mathrm{cde} / \mathrm{cde}$ & Maternal $R H D \psi$ & cde/cde \\
\hline 5 & $\mathrm{C} / \mathrm{A}$ & $+(35.7)$ & - & - & - & cde/cde & Paternal RHD $\psi$ & cde/cde \\
\hline 6 & $\mathrm{C} / \mathrm{A}$ & $+(34.9)$ & - & - & - & cde/cde & Paternal $R H D \psi$ & cde/cde \\
\hline 7 & $\mathrm{C} / \mathrm{A}$ & $+(37.0)$ & - & - & - & cde/cde & Paternal $R H D \psi$ & cde/cde \\
\hline 8 & $\mathrm{~A} / \mathrm{U}$ & $+(33.1)$ & - & + & - & $\underline{\text { Cde }} /$ cde & Maternal $R H D-C E-D$ & $\mathrm{cde} / \mathrm{cde}$ \\
\hline 9 & $\mathrm{~A} / \mathrm{A}$ & $+(30.1)$ & - & + & - & $\underline{\text { Cde }} /$ cde & Maternal $R H D-C E-D$ & $\underline{\text { Cde }} /$ cde \\
\hline 10 & $\mathrm{~A} / \mathrm{A}$ & $+(35.5)$ & - & - & - & cde/cde & Paternal $R H D-C E-D$ & $\underline{\text { Cde }} /$ cde \\
\hline
\end{tabular}

$\mathrm{A}=$ Black African; $\mathrm{C}=$ Caucasian; $\mathrm{U}=$ Unknown; 5th percentile of exon $10 \mathrm{Ct}$ value, 34.5. 
TABLE 5. Weak D women excluded from prenatal prediction

\begin{tabular}{|c|c|c|c|c|c|c|c|}
\hline \multirow[b]{3}{*}{ Patients } & \multirow[b]{3}{*}{ gw } & \multicolumn{5}{|c|}{$\mathrm{Ct}$ value (mean) } & \multirow{3}{*}{$\begin{array}{l}\text { Maternal Rh } \\
\text { CE phenotype }\end{array}$} \\
\hline & & \multirow[b]{2}{*}{$\begin{array}{c}\text { Exon } 4(\mathrm{P} 5, \\
37.8)\end{array}$} & \multirow[b]{2}{*}{$\begin{array}{c}\text { Exon } 5(\mathrm{P} 5, \\
34.0) \\
\end{array}$} & \multirow[b]{2}{*}{ Exon $10(\mathrm{P} 5,34.5)$} & \multicolumn{2}{|c|}{ SRY } & \\
\hline & & & & & $\begin{array}{c}\text { du. (P5, } \\
35.0)\end{array}$ & $\overline{\mathrm{mo} .(\mathrm{P} 5,35.2)}$ & \\
\hline 1 & 14.5 & 36.0 & 31.8 & 32.7 & & & ccEe \\
\hline 2 & 17.0 & 37.2 & 33.0 & 33.9 & 37.0 & 37.8 & $\mathrm{cc} \overline{\mathbf{E}} \mathrm{e}$ \\
\hline 3 & 16.0 & 35.4 & 30.8 & 31.8 & 36.7 & 38.3 & $\operatorname{cc} \overline{\bar{E}} \mathrm{e}$ \\
\hline 4 & 17.2 & 36.1 & 32.3 & 33.6 & 36.5 & 37.1 & Cㅡㄹee \\
\hline 5 & 20.3 & 36.8 & 32.4 & 32.6 & 37.4 & 38.1 & ccee \\
\hline
\end{tabular}

$\mathrm{gW}=$ gestational week; du. $=$ duplex assay for exon 5 and SRY; mo. $=$ monoplex assay; P5 = 5th percentile

\section{Examination of patients presenting isolated amplification of exon 10}

For exon 4 and 5 real-time PCR, the specificity was 100 percent (no sequences were amplified for any pregnancies with $\mathrm{D}$ - fetuses) except for one unusual false-positive. The fetal $\mathrm{RhD}$ status prediction was accurate in spite of maternal or paternal nonfunctional genes. Ten patients with isolated amplification of exon 10 gave birth to $10 \mathrm{D}$ - newborns (Table 4). The specificity of exon 10 real-time PCR was 94.6 percent. The patients were either black African or had a black African partner. RHD geno-typing on maternal-paternal WBC DNA confirmed the presence of $R H D \psi$ in four women and three partners, and the presence of a hybrid RHD-CE-D gene was suggested in two women and one partner. The hybrid gene was associated with the Cde haplotype. In our small population of black African women bearing a $R H D$ - fetus $(\mathrm{n}=9)$, the frequency of those carrying an $R H D \psi$ gene was 44 percent (4/9) and the frequency of those harboring a hybrid gene was 22 percent (2/9). When the $\mathrm{Ct}$ value of exon 10 amplification was less than 34.5 (5th percentile), this suggested that the silent gene was of maternal origin. A Ct value of greater than 34.5 suggested that the fetus had inherited a silent gene from his father.

\section{Weak D women were excluded from prenatal prediction}

Fetal $R H D$ genotypes could not be determined from five specimens ( $0.9 \%)$ of patients typed as D- (Table 5). In these patients, all real-time PCR assays of the RHD sequences had a Ct value of less than the 5th percentile, a value too low to be automatically attributable to fetal origin. The Ct value of $S R Y$ real-time PCR was high when the fetal sex was male. Analysis of DNA from the maternal WBCs, however, revealed RHD sequences in the maternal genome. The search for weak expression of the D antigen with IAT confirmed these results. It should be noted that four of five patients presented either Cde or cdE haplotypes.

Three $R H D$ - D- patients $(0.5 \%)$, bearing a RHD+ fetus, also had Ct real-time PCR assay results in the lower 5 th percentile. The fetuses were predicted $\mathrm{D}+$ because their mothers had neither a weak expression of D by IAT nor $R H D$ exon 4,5 , and 10 sequences in their genome.

\section{Results of twin pregnancies}

Fetal RHD genotyping from the plasma was performed on 18 twin pregnancies (Table 6). The incidence of twin pregnancies was 3.2 percent. The absence of $R H D$ sequence amplification excluded the presence of $R H D$ in the twins (no false-negative results were observed). $R H D+$ real-time PCR predicted at least one $\mathrm{D}+$ fetus.

\section{DISCUSSION}

The correlation between $\mathrm{Ct}$ value and week of gestation is not surprising because the concentration of cell-free fetal DNA increases with gestational age. ${ }^{20}$ The wide range of $\mathrm{Ct}$ values in each real-time-PCR and the poor repeatability of some replicates was partly due to the variability of target copy number in the maternal plasma. The variability of $\mathrm{Ct}$ value between $R H D$ exon (and $S R Y$ ) amplification was probably attributable to individual sampling variation in the extracted DNA eluates or differences in the efficiency and sensitivity of each real-time PCR assay. These data highlight the importance of performing several replicates from each maternal sample and 
of testing several $R H D$-specific sequences to increase the probability of fetal DNA detection and avoid falsenegatives. A total of 3.9 percent of $\mathrm{D}+$ fetus would have been missed if testing for exon 5 and/or exon 10 had been omitted. Chan and colleagues ${ }^{21}$ suggest that most fetal-derived DNA molecules in the maternal circulation are small ( $<313 \mathrm{bp}$ in length). ${ }^{21}$ This does not explain, however, the lower real-time PCR sensitivity for exon 4 , because the length of the exon 4 amplicon is similar to those of other RHD amplicons. Another hypothesis would state that real-time PCR for exon 4 would be less sensitive because the cell-free fetal DNA is not randomly fragmented and the digestion site is located within the chosen sequence of DNA for amplification. ${ }^{22}$

The $S R Y$-based internal positive control is only applicable for pregnancies carrying a male fetus. Indeed, the extent to which negative amplification of both the $R H D$-and the $S R Y$-specific sequences is predictive of an $R H D$ female fetus or a false-negative result due to low fetal DNA concentration cannot be determined. This is why a universal positive control to detect fetal DNA has recendy been proposed. ${ }^{23}$ This is based on the detection of a hyper-methylated DNA sequence of RASSF41A. This gene is hypermethylated in placental cells, a major source of fetal DNA in the maternal plasma, and hypomethylated in maternal blood cells. Although this approach is less complex than the use of other fetal epigenetic markers (hypomethylated maspin) ${ }^{24}$ or genetic polymorphisms, ${ }^{25}$ its feasibility should be evaluated in a routine practice. Nevertheless, neither our lab nor others have observed any false-negative results. ${ }^{13,26}$ Because there are no suitable positive controls for $R H D$ - female fetuses, the "Collège National des Gynécologues et Obstétriciens Français" recommends analyzing additional maternal plasma samples a few weeks later. ${ }^{27}$

D- phenotypes and anti-D-alloimmunized people are quite prevalent in Caucasians (15-17\%), moderately prevalent in Africans (3-5\%), and rare in Asian populations $(<0.1 \%) .{ }^{28}$ In Caucasians, deletion of the entire $R H D$ gene is the most common cause of the D-phenotype. ${ }^{29}$ In contrast, a D-phenotype in Africans and Asians is most often the result of an inactive or silent $R H D$. Sixty-seven percent of D- black Africans have the $R H D$ pseudogene, $R H D \psi$, and 15 percent carry a hybrid $R H D-C E-D^{S}$ gene in which the $R H C E$ segments encompass exons 4 through $7 .^{18,30}$ In this study, the frequency of such genes was 44 and 22 percent, respectively. These two nonfunctional alleles contain an intact $R H D$ exon 10 that is recognized by PCR. ${ }^{12,17}$ The RHD-CE-D ${ }^{\mathrm{s}}$ is associated with $\mathrm{Cde}^{\mathrm{s}}$ haplotype (r's). ${ }^{31}$ In white persons, antigen $\mathrm{D}-\mathrm{RHD}+$ alleles are rare and known to preferentially occur in the Cde and cdE haplotypes. ${ }^{32}$ The molecular bases of these alleles are most frequently associated to hybrid RHD-CE-D genes ${ }^{33}$ with an intact $R H D$ exon 10 . Thus, $R H D$ genotyping based solely on the $R H D$-specific sequence in exon 10 should not be utilized, and testing of two or more "diagnostic sites" should be required to limit the rate of false-positives. ${ }^{34}$ Moreover, the use of PCR to target multiple exons of the $R H D$ gene decreases the probability of not detecting a paternal functional gene with rearrangement inherited by the fetus. ${ }^{35}$

TABLE 6. Results of twin pregnancies: comparison between fetal genotype and twin phenotypes

\begin{tabular}{|c|c|c|c|c|c|c|c|c|}
\hline \multirow[b]{3}{*}{ Patients } & \multirow[b]{3}{*}{ gw } & \multirow{2}{*}{\multicolumn{2}{|c|}{$\begin{array}{c}\text { Real-time PCR } \\
\text { genotype }\end{array}$}} & \multicolumn{4}{|c|}{ Fetal phenotype } & \\
\hline & & & & \multicolumn{2}{|c|}{ First newborn } & \multicolumn{2}{|c|}{ Second newborn } & \\
\hline & & RHD & $S R Y$ & RhD & Sex & $\mathrm{RhD}$ & Sex & \\
\hline 1 & 36.2 & + & + & - & $\mathrm{F}$ & + & $\mathrm{M}$ & NA \\
\hline 2 & 24.2 & - & + & - & M & - & M & mon bia \\
\hline 3 & 15.1 & + & + & + & M & + & M & bic bia \\
\hline 4 & 20.5 & + & + & + & $\mathrm{F}$ & - & M & NA \\
\hline 5 & 18.0 & - & + & - & $\mathrm{F}$ & - & M & NA \\
\hline 6 & 12.0 & + & - & + & $\mathrm{F}$ & + & $\mathrm{F}$ & mon bia \\
\hline 7 & 30.0 & + & + & + & M & + & M & NA \\
\hline 8 & 25.4 & + & - & + & $\mathrm{F}$ & + & $\mathrm{F}$ & mon bia \\
\hline 9 & 17.1 & + & - & + & $\mathrm{F}$ & + & $\mathrm{F}$ & NA \\
\hline 10 & 14.0 & + & + & + & M & + & M & NA \\
\hline 11 & 16.0 & + & + & + & $\mathrm{M}$ & + & M & NA \\
\hline 12 & 17.0 & + & + & + & $\mathrm{M}$ & + & M & bic bia \\
\hline 13 & 14.2 & + & + & + & M & + & $\mathrm{F}$ & bic bia \\
\hline 14 & 29.0 & - & - & - & $\mathrm{F}$ & - & $\mathrm{F}$ & NA \\
\hline 15 & 29.4 & + & - & + & $\mathrm{F}$ & + & $\mathrm{F}$ & NA \\
\hline 16 & 23.0 & + & + & + & $\mathrm{M}$ & + & M & bic bia \\
\hline 17 & 16.2 & + & + & + & M & + & $\mathrm{F}$ & bic bia \\
\hline 18 & 19.5 & - & + & - & $\mathrm{F}$ & - & $\mathrm{M}$ & bic bia \\
\hline
\end{tabular}

$\mathrm{gw}=$ gestational week $;+=$ positive $;-=$ negative mon = monochorionic $;$ bic $=$ bichorionic $;$ bia $=$ biamniotic $; \mathrm{NA}=$ not available; $\mathrm{F}=$ female; $\mathrm{M}=$ male. 
The Guidelines for Prenatal and Perinatal Immunohematology (edited by AABB) say that testing apparent D-women for weak D expression is not required. ${ }^{36}$ The majority of individuals with a weak D phenotype are weak D types 1,2 , and 3 and cannot so far be anti-D-immunized. ${ }^{37,38}$ These weak D patients carry a $R H D$ gene that encodes for lowered D immunoreactivity. Thus, molecular fetal RHD typing with maternal plasma should uncover a maternal $R H D$ gene in these D- women and the risk of erroneously defining the RHD gene as being of fetal origin should be considered. For these reasons, we now systematically test for weak D by IAT all D- women who are referred for fetal RHD genotyping. Fetal RHD genotyping is not performed in nonalloimmunized women with a positive weak D test.

Some partial D, however, also present a weak expression of D. They constitute a small fraction of weak D phenotype. Among these D partial, the DVI are the most frequent in white persons and the carriers are prone to anti-D immunization. Therefore, in some countries, testing for weak D is accompanied by tests for DVI or other $\mathrm{D}$ variants with a selected panel of $\mathrm{D}$-specific monoclonal antibodies directed against different epitopes of $\mathrm{D}$. The molecular basis of partial DVI are $R H D-C E-D$ alleles, coding for altered D proteins. ${ }^{39}$ By real-time PCR targeting exons 4,5 , and 10, partial DVI give also an isolated positivity of exon $10 .{ }^{17}$ This pattern is similar to that of $R H D \psi$ or $R H D-C E-D^{s}$. Therefore, if DVI women are assigned D-(IAT not performed), the knowledge of the ethnic origin of both parents is essential because DVI are associated with Caucasians and the two inactive genes with Africans. This ethnic information must always be joined with the fetal genotyping request for a correct interpretation of results patterns suggesting $R H D$ variants.

Approximately 0.2 to 1 percent of D- Europeans have a weak D. ${ }^{40}$ In our study, the prevalence was 5 of 563 $(0.9 \%)$. The proportion is higher when the D- patient carries a $\mathrm{C}$ or E antigen, ${ }^{33}$ so an alternative to IAT to detect weak D would be to perform a RHD genotyping of serologically D-, C+, and/or E+ pregnant women, before fetal DNA typing from her plasma. The fetal $\mathrm{RhD}$ status from maternal plasma would be determined with real-time PCR targeting the lacking RHD exons in maternal genomic DNA. In our series, no positive amplification of $R H D$ exons 4,5 , and 10 of maternal origin was found in women typed D- by IAT.

In the first two discordant cases (Cases 1 and 2), an error in cord blood collection was the most probable explanation (Table 2). Because of the frequency of this type of error (e.g., poor identification or mixture of cord blood with maternal blood) and to decrease the incidence of anti-D alloimmunization, the French Society of Blood Transfusion (SFTS) and the French Society of Perinatology (SFMP) recommend ABO/RhD typing a cord sample of all babies born from a D- mother and in the case of D-results, controlling for the D of the newborn by a second blood sample. ${ }^{41}$ Infants born from D- women should be tested not only for D but also for weak D so that appropriate RhIG prophylaxis can be administered to the mother ${ }^{36}$ (Case 3). Most false-positive RHD typing results are due to silent $R H D$ variants or the $R H D$ of weak D patients. The presence of donor-specific DNA in the plasma of organ recipients, however, as was observed in Case 4, may also lead to a false-positive result. Previous studies indicate that in organ transplantation recipients, microchimerism is present in peripheral blood and plasma. ${ }^{42}$ Thus, we strongly recommend conducting a thorough clinical history, including questions about solid organ and stem cell transplantation, before performing analyses.

Twin pregnancies run a higher risk of obstetrical complications, explaining their high prevalence in our maternal intensive care center. Fetal RHD genotyping also helps clinicians to manage twin pregnancies from D- mothers. The accuracy of prediction depends on whether the twins' status is dizygotic or monozygotic. No significant association was found between the concentration of fetal DNA ( $\mathrm{Ct}$ value) in the maternal circulation and chorionicity during pregnancy. ${ }^{43}$

Since 2006, noninvasive fetal RHD genotyping has been proposed to all D- pregnant women at our hospital. Although no national policy about the systematic antenatal RhIG prophylaxis exists in Belgium, this is proposed locally, at 28 weeks' gestation, to our patients bearing D+ fetuses. In several European countries where routine antenatal RhIG prophylaxis is offered to all D- pregnant women, large-scale studies are being conducted to enable such a strategy. ${ }^{44-46}$ The feasibility of mass testing for the fetal RHD genotype with maternal plasma is highly desirable for ethical and economical reasons. Indeed, it avoids unnecessary administration of RhIG, blood-derived products, to approximately 40 percent of D- women bearing D- fetuses. Moreover, these teams are evaluating automated approaches not only to allow a mass screening but also to decrease the assay costs below the price of RhIG, with a high accuracy of fetal RHD prediction. In the Dutch situation, the implementation of this strategy is cost-effective. ${ }^{45}$ 


\section{CONCLUSIONS}

Noninvasive fetal RHD genotyping by targeting multiple exons with real-time PCR is highly sensitive and accurate. It is the best method for assessing D fetal status in D-mothers and is the first step in identifying fetuses at risk for anti-D HDFN at the time of the first affected pregnancy or any subsequent ones. Our algorithms for the clinical management of Rh D- anti-D-alloimmunized patients that were initially derived from Moise ${ }^{35}$ have been consistently modified for four years. They simplify the routine serologic testing of D- non-anti-Dimmunized women bearing an $R H D$ - fetus and promote the use of antenatal RhIG prophylaxis in a rational approach. From a more human and psychological viewpoint, this method decreases patients' anxiety on the basis of concrete arguments. It is important for any laboratory that plans to practice this type of analysis to have good expertise in the fields of immunohematology and molecular biology. A close relationship with obstetricians and pediatricians is also essential.

\section{ACKNOWLEDGMENTS}

The authors thank R.M. Rensonnet, C. Willaume, and G. Pirlot for their technical assistance, and the obstetricians for providing clinical data.

\section{REFERENCES}

1. Daniels G. Blood group antibodies in haemolytic disease of the fetus and newborn. In: Hadley A, Soothill P, editors. Alloimmune disorders of pregnancy. Cambridge: Cambridge University Press; 2002. p. 21-40.

2. Wood K. Standard haematology practice/3 - guidelines for blood grouping and red-cell antibody testing during pregnancy and for performing red-cell alloantibody titrations. Oxford: Blackwell Science Ltd; 2000. p. 201-6.

3. Judd WJ. Practice guidelines for prenatal and perinatal immunohematology, revised. Transfusion 2001;41:1445-52

4. Lo YM, Corbetta N, Chamberlain PF, Rai V, Sargent IL, Redman CW. Presence of fetal DNA in maternal plasma and serum. Lancet 1997;350:485-7.

5. Lo YM, Hjelm NM, Fidler C, Sargent IL, Murphy MF, Chamberlain PF, Poon PM, Redman CW, Wainscoat IS. Prenatal diagnosis of fetal RhD status by molecular analysis of maternal plasma. N Engl J Med 1998;339:1734-8.

6. Faas BH, Beuling EA, von Christiaens GC, dem Borne AE, van der Schoot CE. Detection of fetal RHD-specific sequence in maternal plasma. Lancet 1998;352:1196.

7. Mari G. Noninvasive diagnosis by Doppler ultrasonography of fetal anemia due to maternal red-cell alloimmunization. Collaborative Group for Doppler Assessment of the Blood Velocity in Anemic Fetuses. N Engl J Med 2000;342:9-14.

8. Oepkes D, Seaward PG, Vandenbussche FP, Windrin R, Kingdom J, Beyene J, Kanhai HH, Ohlsson A, Ryan G Doppler ultrasonography versus amniocentesis to predict fetal anemia. N Engl J Med 2006;355:156-64.

9. Moise KJ. Diagnosing hemolytic disease of the fetus_- time to put the needles away ? N Engl J Med 2006;355: 192-4.

10. Daniels G, Finning K, Martin P, Soothill P. Fetal blood group from DNA maternal plasma: an important advance in the management and prevention of haemolytic disease of the fetus and newborn. Vox Sang 2004;87:225-32.

11. Finning K, Martin P, Daniela G. A clinical service in the UK to predict fetal Rh (Rhesus) D blood using free fetal DNA in maternal plasma. Ann N YAcad Sci 2004;1022:119-23.

12. Rouillac-Le Sciellour C, Puillandre P, Gillot R, Baulard C, Métral S, Le Van Kim C, Cartron JP, Colin Y, Brossard Y. Large-scale prediagnosis study of fetal RHD genotyping by PCR on plasma DNA from RhD-negative pregnant women. Mol Diagn 2004;8:23-31.

13. Gautier E, Benachi A, Giovangrandi Y, Ernault P, Olivi M, Gaillon Th, Costa JM. Fetal Rh D genotyping by maternal serum analysis: a two-year experience. Am J Obstet Gynecol 2005;192:666-9.

14. van der Schoot CE, Soussan AA, Koelewijn J, Bonsel G, Paget-Christiaens LG, de Haas M. Non-invasive antenatal RHD typing. Transfus Clin Biol 2006;13:53-7. 
15. Bianchi DW, Avent NA, Costa IM, van der Schoot CE. Noninvasive prenatal diagnosis of fetal Rhesus D: ready for prime(r) time. Obstet Gynecol 2005;106:841-4.

16. Minon JM, Schaaps JP, Retz MC, Dricot JF, Foidart JM, Senterre JM. Prenatal determination of fetal RHD in maternal plasma: twoyears experience of routine clinical use. J Gynecol Obstet Biol Reprod (Paris) 2005;34:448-53.

17. Finning KM, Martin PG, Soothill P, Avent ND. Prediction of fetal D status from maternal plasma: introduction of a new non invasive fetal $R H D$ genotyping service. Transfusion 2002;42:1079-85.

18. Singleton BK, Green CA, Avent ND, Martin PG, Smart E, Daka A, Narter-Olaga EG, Hawthorme LM, Daniels G. The presence of an RHD pseudogene containing a 37 base pair duplication and a nonsense mutation in Africans with the RhD negative blood group phenotype. Blood 2000;95:12-8

19. Minon JM, Senterre JM, Schaaps JP, Foidart JM. An unusual false-positive fetal RHD typing result using DNA derived from maternal plasma from a solid organ transplant recipient. Transfusion 2006;46: 1454-5.

20. Lo YM, Tein MS, Lau TK, Haines CJ, Leung TN, Poon PM, Wainscoat IS, Johnson PJ, Chang AM, Hjelm NM. Quantitative analysis of fetal DNA in maternal plasma and serum: implications for noninvasive prenatal diagnosis. Am J Hum Genet 1998;62:768-75.

21. Chan KC, Zhang I, Hui AB, Wong N, Lau TK, Leung TN, Lo KW, Huang DW, Lo YM. Size distributions of maternal and fetal DNA in maternal plasma. Clin Chem 2004;50:88-92.

22. Grootkerk MG, Sousaan AA, de Haas M, Maaskant-van Wijk PA, van der Schoot CE. Evaluation of prenatal RHD typing strategies on cell-free fetal DNA from maternal plasma. Transfusion 2006;46:2142-8.

23. Chan KC, Ding C, Gerovassili A, Yeung SW, Chiu RW, Leung TN, Lau TK, Chim SS, Chung GT, Nicolaides KH, Lo YM. Hypermethylated RAAFIA in maternal plasma: a universal fetal DNA marker that improves the reliability of noninvasive prenatal diagnosis. Clin Chem 2006;52: 2211-8.

24. Chim SS, Tong YK, Chiu RW, Lau TK, Leung TN, Chan LY, Oudejans CB, Ding C, Lo YM. Detection of the placental epigenetic signature of the maspin gene in maternal plasma. Proc Natl Acad Sci USA 2005; 102:14753-8.

25. Page-Christiaens GC, Bossers B, van der Schoot CE, de Haas M. Use of bi-allelic insertion/deletion polymorphisms as a positive control for fetal genotyping in maternal blood: first clinical experience. Ann N Y Acad Sci 2006; 1075:123-9.

26. Costa JM, Giovangrandi Y, Ernault P, Lohmann L, Nataf V, El Halai N, Gautier E. Fetal RHD genotyping in maternal serum during the first trimester of pregnancy. Br J Haematol 2002;119:255-60.

27. Cortey A, Brossard Y, Beliard R, Bourel D. Prévention de l'allo-immunistion Rhesus-D foeto-maternelle: perspectives. J Gynecol Obstet Biol Reprod (Paris) 2006;35:1S119-1S122

28. Westhoff CM. The Rh blood group system in press: a new face for the next decade. Transfusion 2004;44:1663-73.

29. Colin Y, Cherif-Zahar B, Le Van Kim C, Raynal V, Van Huffel V, Cartron JP. Genetic basis of the RhD positive and RhD negative blood group polymorphism as determined by Southern analysis. Blood 1991;78:2747- 52 .

30. Faas BH, Beckers EA, Wildoer P, Ligthart PC, Overbeeke MA, von Zondervan HA, dem Borne AE, van der Schoot CE. Molecular background of VS and weak C expression in blacks. Transfusion 1997;37:38-44.

31. Tax MG, van der Schoot CE, van Doom R, Douglas-Berger L, van Rhenen DJ, Maaskant-van Wijk PA. RHC and $R H c$ genotyping in different ethnic groups. Transfusion 2002;42: 634-44.

32. Wagner FF, Frohmajer A, Flegel WA. RHD positive haplo-types in D negative Europeans. BMC Genet 2001;2:10.

33. Gassner C, Doescher A, Drnovsek Rozman P, Eicher NI, Legler TJ, Lukin S, Garritsen H, Kleinrath T, Egger B, Ehling R, Körmöczi GF, Kilga-Nogler S, Schoenitzer D, Peter-shofen EK. Presence of RHD in serologically D-, C/E+ individuals: a European multicenter study. Transfusion 2005;45:527-38

34. Flegel WA, Wagner FF. Molecular genetics of $R H$. Vox Sang 2000;78:109-15.

35. Moise KJ. Red blood cell alloimmunization in pregnancy. Semin Hematol 2005;42:169-78.

36. Judd WJ, editor. Guidelines for prenatal and perinatal immunohematology. Bethesda (MD): American Association of Blood Banks; 2005.

37. Flegel WA, Wagner FF. Molecular biology of partial D and weak D: implications for blood bank practice. Clin Lab 2002;48:53-9.

38. Flegel WA. Molecular genetics of RH and its clinical applications. Transfus Clin Biol 2006;13:4-12. 
Published in : Transfusion (2008), vol. 48, iss. 2, pp. 373-381

Status: Postprint (Author's version)

39. Wagner FF, Gassner C, Millier TH, Schönitzer D, Schunter F, Flegel WA. Three molecular structures cause Rhesus D category VI phenotypes with distinct immunohematologic features. Blood 1998;91:2157-68.

40. Wagner FF, Gassner C, Müller TH, Schönitzer D, Schunter F, Flegel WA. Molecular basis of weak D phenotypes. Blood 1999;93:385-

41. Mannessier L, Alie-Daram S, Roubinet F, Brossard Y Prevention of fetal hemolytic disease: it is time to take action! Transfus Clin Biol $2000 ; 7: 527-32$

42. Lo YM, Tein MS, Pang CC, Yeung CK, Tong KL, Hjelm NM. Presence of donor-specific DNA in plasma of kidney and liver transplant recipients [letter]. Lancet 1998;351: 1329-30.

43. Smid M, Galbiati S, Vassallo A, Gambini D, Ferrari A, Restagno G, Viora E, Pagliano M, Calza S, Ferrari M, Cremonesi L. Fetal DNA in maternal plasma in twin pregnancies. Clin Chem 2003;49:1526-8.

44. Daniels G, Finning K, Martin P, Summers I. Fetal blood group genotyping: present and future. Ann N YAcad Sci 2006;1075:88-95.

45. van der Schoot CE, Soussan AA, Koelewijn I, Bonsel G, Paget-Chritiaens LG, de Haas M. Non-invasive antenatal RHD typing. Transfus Clin Biol 2006;13:53-7.

46. Legler I, Damme S, Müller S. The German feasibility study on non-invasive determination of the fetal D-status from maternal plasma for decision making on RH-prophylaxis. Vox Sang 2007;93 Suppl 1:53. 